\title{
ANALISIS PENGARUH BRAND IMAGE TERHADAP KEPUTUSAN KONSUMEN PADA BPR SEJAHTERA BATAM
}

\author{
Lukmanul Hakim \\ Dosen Tetap Prodi Manajemen Universitas Riau Kepulauan Batam
}

\begin{abstract}
ABSTRAK
Analisis Pengaruh Brand Image Terhadap Keputusan Konsumen Pada BPR Sejahtera Batam ". Tujuan dari penelitian ini adalah untuk mengetahui besarnya pengaruh brand image terhadap keputusan konsumen BPR Sejahtera Batam, serta untuk menganalisis dari variabel bebas mana yang paling berpengaruh terhadap keputusan konsumen dalam membeli produk BPR Sejahtera Batam. Jenis data yang di gunakan adalah data kualitatif yang di peroleh dari jawaban kuesioner yang di sebarkan kepada sejumlah responden dengan jumlah populasi 773 nasabah, jumlah sampel dalam penelitian ini yaitu 89 responden di tentukan dengan rumus Slovin dengan tingkat kesalahan $10 \%$, dan teknik pengujian data pada penelitian ini meliputi uji validitas, uji reliabilitas, dan analisis regresi linear berganda
\end{abstract}

Pengujian hipotesis dengan menggunakan uji t dapat di simpulkan. Pertama terdapat pengaruh yang positif dan signifikan dari variabel bebas (citra produsen) terhadap variabel terikat (keputusan konsumen). Hal ini terbukti dari nilai positif uji $\mathrm{t}$ dengan nilai $\mathrm{t}_{\text {hitung }} 2.051>\mathrm{t}_{\text {tabel }} 1,663$ serta memiliki nilai signifikan sesbesar 0,043 yang lebih kecil dari 0,05. Kedua terdapat pengaruh yang positif dan signifikan dari variabel bebas (citra konsumen) terhadap variabel terikat (keputusan konsumen). Hal ini terbukti dari nilai positif uji t dengan nilai $t_{\text {hitung }} 2.079>t_{\text {tabel }}$ 1,663 serta memiliki nilai signifikan sebesar 0,041 yang lebih kecil dari 0,05. Ketiga terdapat pengaruh yang positif dan signifikan dari variabel bebas (citra produk) terhadap variabel terikat (keputusan konsumen). Hal ini terbukti dari nilai positif uji $t$ dengan nilai thitung $2.336>t_{\text {tabel }} 1,663$ serta memiliki nilai signifikan sebesar 0,022yang lebih kecil dari 0,05. Dari ketiga variabel bebas diatas, variabel citra produk yang memberikan pengaruh yang dominan terhadap keputusan konsumen dalam memilih produk tabungan. Hal ini dapat dilihat dari nilai signifikan $(0,022)$ lebih signifikan di banding variabel lainya.

Kata Kunci : Analisis Pengaruh Brand Image Terhadap Keputusan Konsumen

\section{PENDAHULUAN}

\section{Latar Belakang}

Persaingan bisnis dalam jaman kecepatan, sehingga menuntut perusahaan harus dapat bersikap dan bertindak, hal ini disebabkan karena lingkungan bisnis bergerak sangat dinamis, serta mempunyai ketidakpastian paling besar. Oleh karena itu, dalam abad millennium seperti sekarang ini perusahaan dituntut bersaing secara kompetitif dalam hal menciptakan dan mempertahankan konsumen yang loyal, dan 
salah satunya adalah melalui perang antar merek. Memasuki millennium baru di era globalisasi ini produsen dihadapkan pada persaingan untuk meraih dominasi merek.

Salah satu kegiatan usaha yang paling dominan dan sangat dibutuhkan keberadaannya didunia ekonomi dewasa ini adalah kegiatan usaha distribusi. Fungsi distribusi sebagai intermediasi sangat berperan dalam menunjang pertumbuhan ekonomi suatu bangsa. Selain itu peranan perbankan sebagai penunjang dari keputusan bisnis yang merupakan kebutuhan dari masyarakat untuk melakukan suatu aktivitas perekonomian. Salah satu cara yang dilakukan sehingga akan mempengaruhi konsumen dalam memilih produk masa depan adalah melakukan brand image. Menurut Erna (2008) bahwa brand image adalah persepsi tentang merek yang merupakan refleksi memori konsumen akan asosiasinya pada merek tersebut, kemudian dalam penelitian yang dilakukan oleh Intan Indah Lestari dengan judul penelitian pengaruh brand image terhadap keputusan nasabah dalam memilih tabungan pada PT. Bank Central

Asia Cabang Probolinggo. Hasil penelitian menunjukkan secara parsial citra pemakai, citra produsen dan citra pembuat berpengaruh dan signifikan terhadap keputusan konsumen dalam memilih produk.

Berdasarkan uraian tersebut di atas, maka penulis tertarik untuk mengangkat tema ini lebih dalam dengan memilih judul : "ANALISIS PENGARUH BRAND IMAGE TERHADAP KEPUTUSAN KONSUMEN PADA BPR SEJAHTERA BATAM"

\section{TINJAUAN PUSTAKA}

\section{Pengertian Pemasaran}

Pemasaran merupakan salah satu dari kegiatan-kegiatan pokok yang dilakukan oleh perusahaan untuk mempertahankan kelangsungan hidupnya, untuk berkembang, dan mendapatkan laba. Arti pemasaran sering dikacaukan dengan pengertian-pengertian (1) penjualan, (2) perdagangan, dan (3) distribusi. Padahal isitilah-istilah tersebut hanya merupakan satu bagian dari kegiatan pemasaran secara keseluruhan. Proses pemasar itu dimulai jauh sejak sebelum barang-barang diproduksi, dan tidak berakhir dengan penjualan.

\section{Pengertian Merek dan Manfaat Merek}

Menurut Sumarwan (2003) merek adalah nama penting bagi sebuah produk atau jasa. Merek adalah simbol dan indikator kualitas dari sebuah produk. Merekmerek produk yang sudah lama dikenal oleh konsumen telah menjadi citra bahkan simbol status bagi produk tersebut. Maka tidaklah mengherankan jika merek seringkali dijadikan kriteria dalam mengevaluasi suatu produk.

\section{Pengertian Brand Image (Citra Merek)}

Istilah image ini mulai populer sejak tahun 1950-an, yang dikemukakan dalam berbagai konteks seperti image terhadap organisasi, image terhadap perusahaan, image nasional, image terhadap merek atau brand image, image publik, self-image, dan sebagainya.

Buchari (2003) citra adalah merupakan impresi, perasaan atau konsepsi yang ada pada publik mengenai perusaaan, mengenai suatu object, orang atau mengenai lembaga." 


\section{Komponen yang Membentuk Citra Merek}

Faktor lingkungan dan personal sebagai awal terbentuknya suatu citra merek, karena faktor lingkungan dan personal mempengaruhi persepsi seseorang. Faktor lingkungan yang dapat mempengaruhi adalah atribut-atribut teknis yang ada pada suatu produk dimana faktor ini dapat dikontrol oleh produsen, selain itu juga sosial budaya termasuk dalam faktor ini. Faktor personal adalah kesiapan mental konsumen untuk melakukan proses persepsi, pengalaman konsumen sendiri, mood, kebutuhan serta motivasi konsumen. Citra merupakan produk akhir dari sikap awal dan pengetahuan yang terbentuk lewat proses pengulangan yang dinamis karena pengalaman.

Komponen citra merek (brand image) terdiri atas tiga bagian yaitu :

1. Citra produsen (Production image) yaitu sekumpulan asosiasi yang dipersepsikan konsumen terhadap perusahaan yang membuat suatu barang/jasa. Bagi produsen, manfaat brand adalah :

a. Brand memudahkan penjual mengolah pesanan dan menelusuri masalahmasalah yang timbul.

b. Brand memberikan perlindungan hukum atas keistimewaan atau ciri khas produk.

c. Brand memungkinkan untuk menarik sekelompok pembeli yang setia dan menguntungkan.

d. Brand membantu penjual melakukan segmentasi pasar.

2. Citra Konsumen (Customer image) yaitu sekumpulan asosiasi yang dipersepsikan oleh konsumen terhadap pemakai yang menggunakan suatu barang/jasa. Bagi konsumen, manfaat brand adalah :

a. Brand dapat menceritakan sesuatu kepada pembeli tentang mutu.

b. Brand membantu menarik perhatian pembeli terhadap produk-produk baru yang mungkin bermanfaat bagi mereka.

3. Citra produk (produk image) yaitu sekumpulan asosiasi yang dipersepsikan konsumen terhadap suatu barang/jasa. (http:/jurnal brand image.pdf.Nitropdf.

Professional).

a. Kualitas produk asli atau palsu.

b. Berkualitas baik.

c. Desain menarik.

d. Bermanfaat bagi konsumen. 


\section{Kerangka Pemikiran}

Berdasarkan uraian diatas maka akan disajikan kerangka pikir dalam penelitian ini yaitu sebagai berikut :

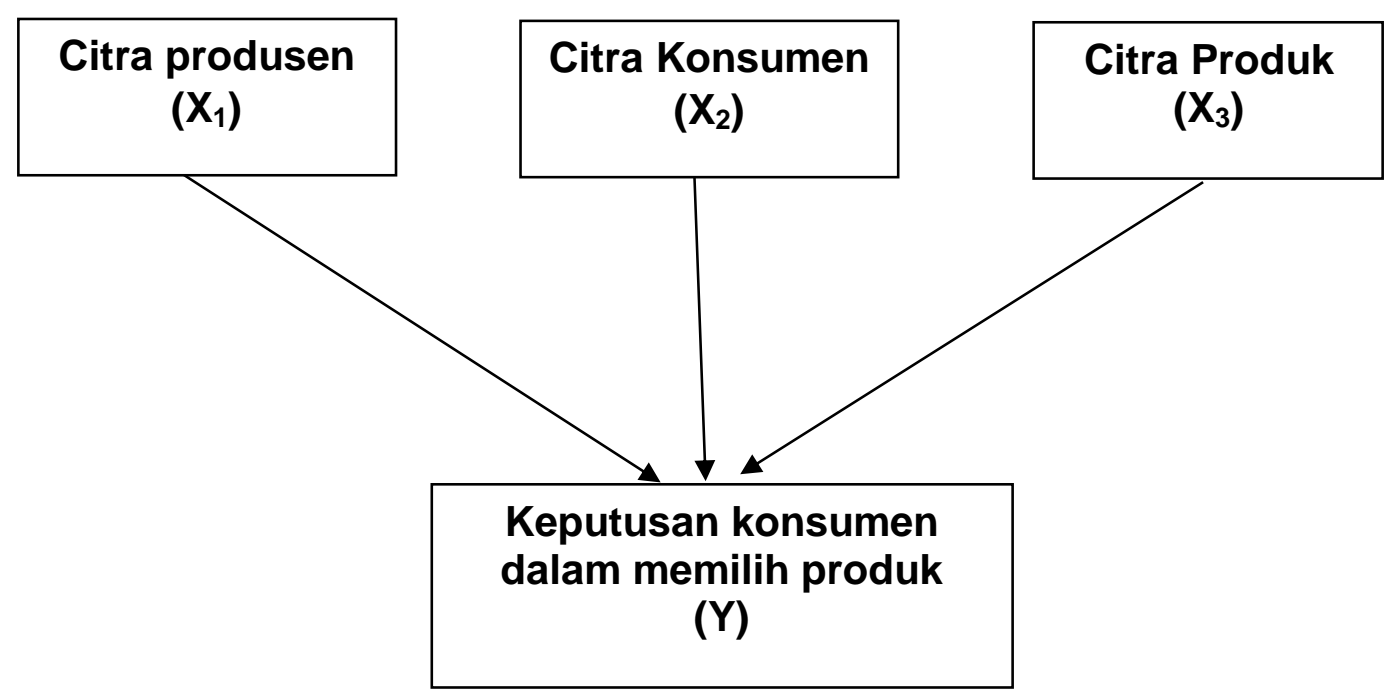

\section{Hipotesis}

Sehubungan dengan rumusan masalah yang telah dikemukakan, maka hipotesis yang diajukan adalah sebagai berikut :

1) Diduga bahwa brand image (citra produsen, citra konsumen dan citra produk) mempunyai pengaruh yang positif/negatif terhadap keputusan konsumen pada BPR Sejahtera Batam.

2) Diduga bahwa variabel brand image yang paling dominan berpengaru terhadap keputusan konsumen pada BPR Sejahtera Batam.

\section{METODE PENELITIAN}

\section{Tempat dan Waktu Penelitian}

Untuk menunjang pembahasan dalam penulisan ini, penulis memusatkan pada obyek tertentu yaitu pada BPR Sejahtera Batam. Sedangkan waktu penelitian diperkirakan tiga bulan di mulai dari bulan Maret 2015 sampai dengan bulan Juni 2015.

\section{Populasi dan Sampel}


Populasi dalam penelitian ini adalah seluruh nasabah pada BPR Sejahtera Batam ditentukan sebesar 773 nasabah. Sedangkan jumlah sampel dalam penelitian ini dapat ditentukan dengan rumus Slovin (Husein Umar, 2003) yaitu :

$$
\begin{aligned}
& \mathrm{n}=\frac{\mathrm{N}}{--------} \\
& 773
\end{aligned}
$$

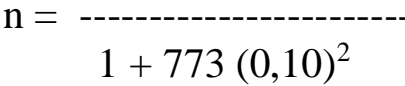

$$
\begin{aligned}
& \mathrm{n}=88,54 \text { dibulatkan } 89 \text { sampel } \\
& \text { Sehingga jumlah sampel penelitian ini ditentu } \\
& \text { kan sebesar } 89 \text { orang. }
\end{aligned}
$$

\section{Jenis dan Sumber Data}

Jenis data yang digunakan adalah data kualitatif yang diperoleh dari jawaban kuesioner yang disebarkan kepada sejumlah responden mengenai keterangan-keterangan secara tertulis mengenai masalah citra merek (Brand Image) yang dapat mempengaruhi nasabah pada BPR Sejahtera Batam.

Sedangkan untuk menunjang pembahasan dalam penelitian ini maka sumber data yang digunakan adalah data primer, yaitu data yang bersumber dari obyek yang diamati, dalam hal ini adalah responden yang diberi kuesioner.

\section{Metode Analisis}

Untuk memecahkan permasalahan pokok yang dihadapi oleh perusahaan, maka digunakan metode analisis sebagai berikut:

1) Analisis Deskriptif adalah suatu analisis yang menguraikan tanggapan responden mengenai citra merek (Brand Image) terhadap keputusan nasabah pada BPR Sejahtera Batam dengan menyebarkan kuesioner kepada konsumen yang menjadi sampel dalam penelitian ini.

2) Analisis Regresi Linear Berganda yaitu suatu analisis untuk menganalisis pengaruh citra merek (Brand Image) Terhadap keputusan konsumen dalam memilih produk masa depan dengan menggunakan rumus yang dikutip dari buku Riduwan dan Akdom (2007 : 142) yaitu:

$$
\mathrm{Y}=\mathrm{b}_{0}+\mathrm{b}_{1} \mathrm{X}_{1}+\mathrm{b}_{2} \mathrm{X}_{2}+\mathrm{b}_{3} \mathrm{X}_{3}+\mathrm{e}
$$

Keterangan:

$\mathrm{Y}=$ Keputusan konsumen dalam memilih produk masa depan

$\mathrm{b}_{0}=$ Nilai constan/reciprocel

$\mathrm{X}_{1}=$ Citra produsen

$\mathrm{X}_{2}=$ Citra konsumen

$\mathrm{X}_{3}=$ Citra produk 
$b_{1}, b_{2}, b_{3}=$ Koefisien regresi,

$\mathrm{e}=$ Standar error

3) Pengujian Hipotesis adalah suatu analisis untuk menguji pengaruh brand image terhadap keputusan konsumen dalam memilih produk masa depan dengan menggunakan uji t dan uji F.

\section{a. Uji t}

Pada tahapan ini dilakukan pengujian pengaruh masing-masing variabel bebas yang terdapat pada model yang terbentuk untuk mengetahui apakah semua variabel bebas yang ada pada model secara individual mempunyai pengaruh yang signifikan pada model secara individual. Jika hasil perhitungan menunjukkan bahwa nilai probabilitas $(\mathrm{P}$ value $)<$ alpha 0,05 , maka Ho ditolak dan $\mathrm{H} 1$ diterima. Dengan demikian variabel bebas dapat menerangkan variabel terikatnya secara parsial.

\section{b. Uji F}

Pada tahapan ini dilakukan pengujian terhadap variabel bebas (X) secara bersama-sama terhadap variabel terikat (Y). Dengan demikian akan dapat diketahui model hubungan fungsional antara variabel tidak bebas (dependent variable) dengan variabel bebasnya (independent variable) yang terbentuk pada penelitian ini. Jika hasil perhitungan menunjukkan bahwa nilai probabilitas $(\mathrm{P}$ value $)<$ alpha 0,05, maka Ho ditolak dan $\mathrm{H} 1$ diterima, sehingga dapat dikatakan bahwa variabel bebas dari model regresi dapat menerangkan variabel terikat secara serempak.

\section{4) Uji reliabilitas}

Uji reliabilitas adalah indeks yang menunjukkan sejauh mana suatu alat pengukur dapat dipercaya/diandalkan. Reliabilitas menunjukkan konsistensi suatu alat pengukur didalam mengukur gejala yang sama, dalam beberapa kali pelaksanaan pengukuran teknik cronbach alpha pada SPSS. Dimana dikatakan reliable jika cronbach alpha> 0,60 (Ghozali, 2005).

\section{5) Uji validitas}

Uji validitas merupakan kemampuan dari indikator-indikator untuk mengukur tingkat keakuratan sebuah konsep. Artinya apakah konsep yang telah dibangun tersebut sudah valid atau belum. Dimana dikatakan valid jika nilai korelasi diatas 0,30 (Sugiyono, 2009).

\section{HASIL PENELITIAN DAN PEMBAHASAN}

\section{Pengujian Validitas dan Reliabilitas}

\section{Pengujian Validitas}

Validitas menunjukkan sejauh mana ketepatan dan kecermatan suatu alat ukur dalam melakukan fungsi ukurnya yaitu menggunakan corrected item total 
correlation dalam SPSS. Jika nilai signifikansi $(\rho$ value $)>0,05$ maka tidak terjadi hubungan yang signifikan. Sedangkan apabila nilai signifikansi ( $\rho$ value) $<0,05$ maka terjadi hubungan yang signifikan. Dari hasil di atas menunjukkan bahwa semua item pernyataan yang digunakan untuk mengukur variabel-variabel yang digunakan dalam penelitian ini mempunyai nilai corrected item total correlation atau nilai korelasi yang di atas dari 0,30, sehingga menurut Sugiyono (2009) bahwa apabila nilai korelasi dibawah dari 0,30 maka butir instrument tersebut tidak valid, sehingga harus diperbaiki atau dibuang, dan apabila di atas dari 0,30 maka butir instrument tersebut sudah valid. Sehingga dapat disimpulkan bahwa dari empat variabel yang diteliti maka semuanya dianggap sudah valid karena memiliki nilai corrected item total correlation di atas dari 0,30.

\section{Pengujian Reliabilitas}

Uji reliabilitas digunakan untuk mengetahui konsistensi alat ukur, apakah alat ukur dapat diandalkan untuk digunakan lebih lanjut. Hasil uji reliabilitas dalam penelitian ini menggunakan koefisien cronbach's alpha, di mana menurut Imam Ghozali (2006) bahwa instrument dikatakan reliabel jika memiliki koefisien cronbach's alpha sama dengan 0,60 atau lebih. Hasil uji reliabilitas data dapat dilihat pada tabel berikut ini :

Hasil uji reliabilitas

\begin{tabular}{|l|l|l|l|}
\hline Variabel & $\begin{array}{l}\text { Cronbach's } \\
\text { Alpha }\end{array}$ & $\begin{array}{l}\text { Cronbach's } \\
\text { Alpha } \\
\text { Standar }\end{array}$ & Keterangan \\
\hline Citra Produsen & 0,799 & 0,60 & Reliabel \\
Citra Konsumen & 0,818 & 0,60 & Reliabel \\
$\begin{array}{l}\text { Citra Produk } \\
\text { Keputusan Memilih } \\
\text { produk rokok }\end{array}$ & 0,756 & 0,60 & Reliabel \\
Reliabel
\end{tabular}

Sumber : Hasil output SPSS

Hasil uji reliabilitas tersebut menunjukkan bahwa semua variabel mempunyai koefisien alpha yang cukup besar yaitu di atas dari 0,60 sehingga dapat disimpulkan bahwa semua item-item pengukur variabel dari kuesioner adalah reliabel yang berarti bahwa kuesioner yang digunakan dalam penelitian ini merupakan kuesioner yang handal.

\section{Analisis dan Pembahasan Regresi Linear Berganda}

Analisis hasil penelitian mengenai pengaruh brand image dan keputusan memilih produk tabungan pada BPR Sejahtera Batam, yang dianalisis dengan menggunakan metode kualitatif dan kuantitatif

Adapun hasil olahan data dengan menggunakan program SPSS 17 (Statistical Package for Social Science 17) dapat dirangkum melalui Hasil perhitungan regresi persamaan regresi linear berganda sebagai berikut : $Y=1,475+0,256 X_{1}+0,264 X_{2}+0,271 X_{3}$ 
Model persamaan regresi yang dapat dituliskan dari hasil tersebut dalam bentuk persamaan regresi standardized adalah sebagai berikut :

1. Koefisien regresi $(\beta)$ bo sebesar 1,475 memberikan arti bahwa tanpa adanya citra produsen, citra konsumen dan citra produk maka keputusan konsumen dalam memilih produk tabungan sebesar 1,475.

2. Koefisien regresi $X_{1}$ sebesar 0,256 memberikan arti bahwa citra produsen berpengaruh positif terhadap keputusan konsumen dalam memilih produk tabungan (Y). Hal ini menunjukkan bahwa dengan penambahan satu satuan citra produsen, maka akan terjadi peningkatan keputusan nasabah dalam memilih produk tabungan sebesar 0,256 dan begitu pun sebaliknya.

3. Koefisien regresi $\mathrm{X}_{2}$ sebesar 0,264 memberikan arti bahwa citra konsumen berpengaruh positif terhadap keputusan konsumen memilih produk tabungan (Y). Hal ini menunjukkan bahwa dengan penambahan satu satuan citra konsumen, maka akan terjadi peningkatan keputusan memilih produk tabungan dalam memilih produk sebesar 0,264 dan begitu pun sebaliknya.

4. Koefisien regresi $X_{3}$ sebesar 0,271 memberikan arti bahwa citra produk berpengaruh positif terhadap keputusan memilih produk tabungan dalam memilih produk (Y). Hal ini menunjukkan bahwa dengan penambahan satu satuan citra produk, maka akan terjadi peningkatan sebesar 0,271 dan begitu pun sebaliknya.

Berdasarkan hasil persamaan regresi maka dapat diketahui bahwa variabel bebas yang paling berpengaruh terhadap keputusan memilih produk tabungan adalah variabel citra produk dengan koefisien beta sebesar 0,271 alasannya karena memiliki nilai beta yang terbesar jika dibandingkan dengan variabel lainnya.

\begin{tabular}{|l|r|r|r|r|r|}
\hline Model & $\begin{array}{r}\text { Sum of } \\
\text { Squares }\end{array}$ & Df & $\begin{array}{r}\text { Mean } \\
\text { Square }\end{array}$ & $\begin{array}{c}\text { F } \\
\text { g }\end{array}$ \\
\hline 1 & 11.712 & 3 & 3.904 & 29 & .0 \\
Regresi & & & & 70 & 0 \\
on & & & & 0 & 0 \\
Residu & 11.170 & 85 & .131 & & \\
al & & & & & \\
Total & & & & & \\
\hline
\end{tabular}


Kemudian diketahui bahwa nilai $\mathrm{R}=0,715$ atau mempunyai hubungan yang kuat karena mendekati 1 , sedangkan nilai koefisien determinasi $\left(\mathrm{R}^{2}\right)$ yang diperoleh sebesar 0,512. Hal ini berarti bahwa 51,2\% (1 x 0,512 x 100\%) keputusan konsumen dalam memilih produk tabungan dapat dijelaskan oleh variabel citra produsen, citra konsumen dan citra produk, sedangkan sisanya yaitu sebesar 48,8\% (1 - 0,512 x 100\%) keputusan konsumen dalam memilih produk tabungan dipengaruhi oleh variabel-variabel lainnya yang tidak diteliti dalam penelitian ini seperti tingkat suku bunga, promosi dan pelayanan.

\section{Pengujian Hipotesis}

Pengujian hipotesis yang dilakukan pada penelitian ini bertujuan untuk melihat bagaimana pengaruh variabel independen terhadap variabel dependen. Pengujian hipotesis ini terdiri atas uji hipotesis secara parsial dan uji hipotesis secara simultan. Adapun hasil dari pengujian tersebut juga akan dijelaskan

\section{Uji Serempak/Simultan (Uji F)}

Uji statistik F pada dasarnya menunjukkan apakah semua variabel independen yang dimasukkan dalam model mempunyai pengaruh secara bersamasama terhadap variabel dependennya. Hasil perhitungan Uji F dapat dilihat pada tabel berikut ini:

Hasil perhitungan uji f (secara simultan)

Sumber : Output SPSS 17

Dari hasil analisis regresi dapat diketahui bahwa secara bersama-sama variabel independen memiliki pengaruh yang signifikan terhadap variabel dependen. Hal ini dibuktikan dari nilai $F_{\text {hitung sebesar } 29.708>F_{\text {tabel }}}$ 2,712 dengan nilai signifikansi (sig) sebesar 0,000. Karena nilai signifikansi (sig) jauh lebih kecil dari 0,05 maka model regresi dapat digunakan untuk memprediksi keputusan konsumen dalam memilih produk tabungan atau dapat dikatakan bahwa citra produsen, citra konsumen dan citra produk secara bersama-sama berpengaruh terhadap keputusan konsumen dalam memilih produk tabungan.

\section{Uji Parsial (Uji t)}

Uji t dilakukan untuk mengetahui pengaruh masing-masing atau secara parsial variabel independen (citra produsen, citra konsumen dan citra produk) terhadap variabel dependen (keputusan konsumen dalam memilih produk rokok). Sementara itu secara parsial pengaruh dari ketiga variabel independen tersebut dapat dilihat pada tabel berikut ini

Hasil perhitungan uji $\mathrm{t}$

\begin{tabular}{|l|l|l|}
\hline Model & thitung & Sig. \\
\hline 1 (constant) & 6.333 & .000 \\
Citra Produsen & 2.051 & .043 \\
Citra Konsumen & 2.079 & .041 \\
\hline
\end{tabular}


Citra produk 2.336

.022

Sumber Pengaruh dari masing-masing variabel citra produsen, citra konsumen dan citra produk terhadap keputusan nasabah dalam memilih produk masa depan dapat dilihat dari arah tanda dan tingkat signifikan (probabilitas). Ketiga produk mempunyai variabel yakni citra produsen, citra konsumen dan citra lebih kecil dari 0,05. Hal ini dapat diuraikan sebagai berikut :

1) Pengaruh citra produsen terhadap keputusan memilih produk pada BPR Sejahtera Batam

Hasil pengujian parsial (uji t) antara variabel citra produsen terhadap variabel keputusan memilih produk tabungan menunjukkan nilai $t_{\text {hitung }}$ sebesar $2.051>\mathrm{t}_{\text {tabel }} 1,663$ serta memiliki nilai probabilitas sebesar 0,043 yang lebih kecil dari 0,05 , hal ini berarti bahwa citra produsen berpengaruh positif terhadap keputusan konsumen dalam memilih produk tabungan mempunyai nilai konstan di setiap kenaikan $1 \%$ citra produsen yang mempengaruhi keputusan konsumen dalam memilih produk tabungan.

Berdasarkan hasil penelitian menunjukkan bahwa citra produsen berpengaruh terhadap keputusan memilih produk tabungan. Hal ini dapat terjadi karena seorang konsumen memilih suatu produk dan akhirnya berpengaruh terhadap keputusan konsumen dikarenakan oleh perusahaan yang membuat citra produsen tersebut.

2) Pengaruh citra konsumen terhadap keputusan konsumen dalam memilih produk tabungan pada BPR Sejahtera Batam

Hasil pengujian parsial (uji t) antara variabel citra konsumen terhadap keputusan konsumen memilih produk tabungan menunjukkan nilai thitung 2.079 $>\mathrm{t}_{\text {tabel }}$ 1,663 serta memiliki nilai probabilitasnya sebesar 0,041 yang lebih kecil dari 0,05 , hal ini berarti bahwa citra konsumen berpengaruh positif terhadap keputusan memilih produk tabungan pada BPR Sejahtera Batam .

3) Pengaruh citra produk terhadap keputusan konsumen dalam memilih produk tabungan pada BPR Sejahtera Batam

Hasil pengujian parsial (uji t) antara variabel citra produk terhadap variabel keputusan memilih produk menunjukkan nilai $t_{\text {hitung }} 2,336>t_{\text {tabel }} 1,663$ serta memiliki nilai probabilitas sebesar 0,022 yang lebih kecil dari 0,05 , hal ini berarti bahwa citra produk berpengaruh positif terhadap keputusan konsumen dalam memilih produk tabungan.

\section{Pembahasan}

Pembahasan dalam penelitian menguraikan pengaruh brand image terhadap keputusan konsumen dalam memilih produk tabungan di BPR Sejahtera Batam . Dimana brand image meliputi : pengaruh citra produsen, citra konsumen dan citra produk terhadap keputusan konsumen dalam memilih produk tabungan pada BPR Sejahtera Batam.

\section{1) Citra produsen terhadap keputusan konsumen}


Citra produsen mempunyai pengaruh terhadap keputusan konsumen dalam memilih produk tabungan, hal ini dapat dilihat dari nilai koefisien regresi yang bertanda positif yakni sebesar 0,256 selain itu memiliki nilai probabilitas $0,043<0,05$, hasil penelitian yang penulis lakukan menunjukkan bahwa citra produsen berpengaruh signifikan terhadap keputusan konsumen dalam memilih produk tabungan yang ditawarkan pada BPR Sejahtera Batam .

Penelitian ini sesuai dengan teori yang dikemukakan oleh Simamora (2008) mengatakan bahwa citra produsen (Production image) yaitu sekumpulan asosiasi yang dipersepsikan konsumen terhadap perusahaan yang membuat suatu barang/jasa, sehingga mempengaruhi konsumen dalam menentukan suatu barang/jasa. Sehingga dengan adanya asosiasi tersebut maka konsumen akan tertarik pada suatu barang atau jasa yang ditawarkan oleh perusahaan. Hasil penelitian yang penulis lakukan menunjukkan bahwa citra produsen mempunyai pengaruh yang signifikan terhadap keputusan konsumen dalam memilih produk tabungan, karena dengan adanya logo atau lambang, pembukaan cabang-cabang yang tersedia, adanya jaminan kualitas pelayanan, serta keluhan dan saran konsumen ditanggapi dengan baik oleh karyawan maka akan mempengaruhi keputusan nasabah dalam memilih produk yang ditawarkan oleh BPR Sejahtera Batam .

Penelitian ini pula sejalan dengan penelitian yang telah dilakukan oleh Yonanda dan Tommy Tansir yang meneliti mengenai pengaruh brand image melalui citra produsen mempengaruhi perilaku konsumen dalam membeli produk blackberry. Sedangkan hasil penelitian yang telah penulis lakukan menunjukkan bahwa citra produsen mempunyai pengaruh yang signifikan terhadap keputusan nasabah dalam memilih produk pada BPR Sejahtera Batam, sehingga dapat disimpulkan bahwa penelitian ini sejalan dengan penelitian yang telah dilakukan oleh peneliti-peneliti sebelumnya yakni sebagaimana dilakukan oleh Yonanda dan Tommy Tansir.

\section{2) Pengaruh citra konsumen terhadap keputusan konsumen}

Citra konsumen mempunyai pengaruh yang signifikan terhadap keputusan konsumen dalam memilih produk pada BPR Sejahtera Batam. Hasil penelitian yang penulis peroleh menunjukkan bahwa dilihat dari analisis koefisien regresi dimana diperoleh nilai regresi sebesar 0,264 serta memiliki nilai probabilitas 0,041 $<0,05$, hal ini berarti bahwa citra konsumen mempunyai pengaruh yang signifikan terhadap keputusan konsumen dalam memilih produk pada BPR Sejahtera Batam.

Hal ini sesuai dengan teori yang dikemukakan oleh Ferrinadewi (2008) berpendapat bahwa :"citra konsumen adalah persepsi tentang merek yang merupakan refleksi memori konsumen akan asosiasinya pada merek tersebut."

Penelitian ini pula sejalan dengan penelitian yang telah dilakukan oleh Yonanda dan Tommy Tansir yang meneliti mengenai Pengaruh Citra Merek (brand image) terhadap keputusan pembelian handphone Blackberrry, dimana penelitian keduanya menemukan bahwa citra konsumen mempunyai pengaruh terhadap pembelian handphone blackberry, sedangkan hasil penelitian yang telah penulis lakukan ditemukan bahwa citra konsumen mempunyai pengaruh yang signifikan terhadap keputusan konsumen dalam memilih produk pada BPR Sejahtera Batam, sehingga dapat dikatakan bahwa penelitian ini sejalan dengan penelitian yang telah dilakukan oleh Yonanda dan Tommy Tansir. 


\section{3) Pengaruh citra produk terhadap keputusan konsumen}

Citra produk berpengaruh terhadap keputusan konsumen dalam memilih produk pada BPR Sejahtera Batam, hal ini dapat dilihat dari nilai koefisien regresi yakni sebesar 0,271 serta memiliki nilai probabilitas $0,022<0,05$, hasil penelitian yang penulis peroleh menemukan bahwa citra produk mempunyai pengaruh yang signifikan terhadap keputusan konsumen dalam memilih produk yang ditawarkan oleh BPR Sejahtera Batam .

Penelitian ini sesuai dengan teori yang dikemukakan oleh Simamora (2008) mengatakan bahwa citra produk (produk image) yaitu sekumpulan asosiasi yang dipersepsikan konsumen terhadap suatu barang/jasa, sehingga mempengaruhi perilaku konsumen.

Penelitian ini sejalan dengan penelitian yang dilakukan oleh Yonanda dan Tommy Tansir yang meneliti mengenai pengaruh Citra Merek (brand image) terhadap keputusan pembelian handphone Blackberrry, dimana penelitian keduanya menemukan bahwa citra konsumen mempunyai pengaruh terhadap pembelian handphone blackberry, sedangkan hasil penelitian yang telah penulis lakukan menemukan bahwa citra produk mempunyai pengaruh yang signifikan terhadap keputusan konsumen dalam memilih produk pada BPR Sejahtera Batam, sehingga dapat disimpulkan bahwa penelitian ini sejalan dengan penelitian yang sebagaimana dilakukan oleh peneliti-peneliti sebelumnya. Perbedaan dari penelitian ini dengan penelitian terdahulu adalah terletak pada obyek penelitian sedangkan persamaannya adalah bahwa brand image mempunyai pengaruh yang signifikan terhadap keputusan konsumen.

\section{KESIMPULAN DAN SARAN}

\section{Kesimpulan}

Penelitian ini bertujuan untuk mengetahui pengaruh brand image dengan dimensi : citra produsen, citra konsumen, citra produk terhadap keputusan konsumen dalam memilih produk dan untuk mengetahui dimensi dari variabel brand image yang paling berpengaruh. Dari rumusan masalah yang diajukan, maka analisis data yang telah dilakukan dan pembahasan yang telah dikemukakan pada bab sebelumnya, maka dapat ditarik beberapa kesimpulan sebagai berikut :

1) Berdasarkan hasil pengujian regresi linear berganda maka diketahui bahwa variabel citra produsen, citra konsumen dan citra produk mempunyai pengaruh yang signifikan terhadap keputusan konsumen dalam memilih produk tabungan pada BPR Sejahtera Batam .

2) Berdasarkan hasil pengujian regresi maka dapat diketahui bahwa variabel yang paling besar pengaruhnya terhadap keputusan konsumen dalam memilih produk rokok adalah variabel citra produk, alasannya karena memiliki nilai beta yang terbesar serta memiliki nilai probabilitas yang terkecil dari variabel lainnya. 
3) Dari hasil pengujian secara serempak dan secara parsial (uji $\mathrm{T}$ dan Uji F) ternyata hasil penelitian membuktikan bahwa semua dimensi (citra produsen, citra konsumen dan citra produk) dari variabel brand image secara simultan mempunyai pengaruh yang signifikan terhadap keputusan konsumen dalam memilih produk, sedangkan variabel dari brand image yang paling berpengaruh terhadap keputusan konsumen dalam memilih produk adalah citra produk.

\section{Saran}

Berdasarkan kesimpulan yang diperoleh dalam penelitian ini, maka diajukan saran sebagai pelengkap terhadap hasil penelitian yang dapat diberikan sebagai berikut :

1) Bagi peneliti selanjutnya, diharapkan dapat meneliti dengan variabel-variabel di luar variabel yang telah diteliti ini agar memperoleh hasil yang lebih bervariatif yang dapat berpengaruh terhadap keputusan konsumen dalam memilih produk tabungan pada BPR Sejahtera Batam .

2) Disarankan agar perusahaan harus mampu mempertahankan atau bahkan meningkatkan citra yang terbentuk untuk para konsumen dalam memilih produk, misalnya dengan memberikan kesadaran kepada konsumen atau mencari tahu harapan-harapan nasabah terhadap produk, karena perlu disadari bahwa mempertahankan konsumen jauh lebih baik dan menguntungkan jika dibandingkan mencari konsumen baru, oleh karenanya BPR Sejahtera Batam perlu untuk lebih memperhatikan mengenai citra serta layanan terhadap konsumenya.

\section{DAFTAR PUSTAKA}

Adelina, Rosa. 2010. Pengaruh brand image terhadap keputusan pembelian konsumen Pizza Hut Semeru Malang. Skripsi

Alma Buchari. 2003. Pemasaran Strategik. Cetakan Kesatu, Penerbit Alfabeta, Bandung

Boyd dkk. 2000. Manajemen Pemasaran: Suatu Pendekatan Strategis dengan Orientasi Global. Jilid Satu, Edisi Kedua, Penerbit Erlangga, Jakarta

Dharmessta, Basu Swastha dan Hani Handoko. 2008. Manajemen Pemasaran : Analisis Perilaku Konsumen. Edisi Pertama, Cetakan Keempat, Penerbit BPFE, Yogyakarta

Ferrinadewi, Erna. 2008. Merek \& Psikologi Konsumen : Implikasi pada Strategi Pemasaran. Edisi Pertama, Cetakan Pertama, Penerbit : Graha Ilmu, Yogyakarta

Ghozali, Imam. 2005. Aplikasi analisis multivariat dengan program SPSS, BP Undip

Kasmir dan Jakfar. 2003. Studi Kelayakan Bisnis. edisi pertama, cetakan pertama, Penerbit : Prenada Media, Jakarta

Kotler, Philip, Keller, Lane, Kevin. 2008. Manajemen Pemasaran. Edisi Ketigabelas, Jilid Satu, Penerbit : Erlangga, Jakarta

Riduwan dan Akdom. 2007. Rumus dan Data Dalam Analisis Statistik. cetakan kedua, Penerbit : Alfabeta, Bandung

Subagyo, Ahmad. 2010. Marketing In Business : Studi Kasus UMK \& LKM. Edisi Asli, Penerbit : Mitra Wacana Media, Jakarta 
Sumarwan, Ujang. 2003. Perilaku Konsumen : Teori dan Penerapannya Dalam Pemasaran. Cetakan Pertama, Penerbit : Ghalia Indonesia, Jakarta

Salusu, I. 2003. Pengambilan Keputusan Stratejik untuk Organisasi Publik dan Organisasi Nonprofit. Penerbit : Grasindo, Jakarta.

Simamora Bilson. 2008. Panduan Riset Perilaku Konsumen. cetakan ketiga, Penerbit : Gramedia Pustaka Utama, Jakarta 
Sugiyono. 2009. Metode Penelitian Administrasi, Dilengkapi dengan Metode,

$R \& D$. edisi revisi cetakan ketujuhbelas, Penerbit : Alfabeta Bandung

Tansir, Tommy. 2012. Analisis Pengaruh Brand Image Terhadap Perilaku Konsumen Dalam Membeli Produk Blackberry Pada Perusahaan Ruby Celluler di Makassar. Skripsi Universitas Atma Jaya Makassar Usmara, Usi. 2008. Pemikiran Kreatif Pemasaran. Cetakan Pertama, Penerbit Amara Books, Yogyakarta

Yonanda. 2012. Pengaruh Citra Merek (Brand Image) Terhadap Keputusan Pembelian handphone Blackberrry. Universitas Diponegoro Semarang. 